\title{
山林樹實類の䬲料化試驗（第二報）
}

\author{
筧類團栗の一般成分
}

岩时久敬

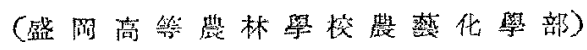

\begin{abstract}
I. 粕言

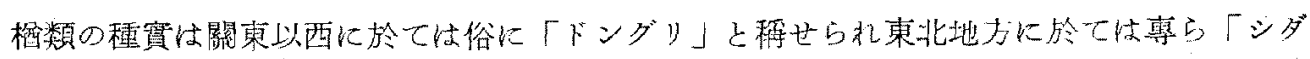

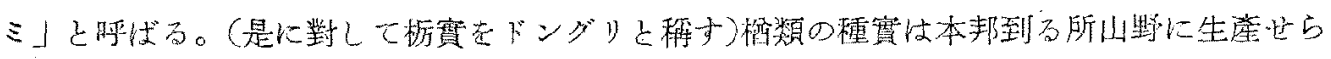

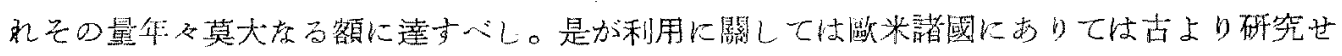

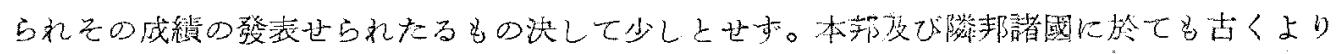

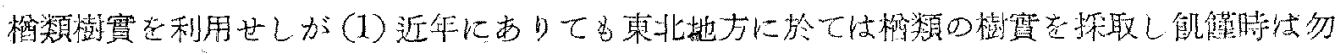

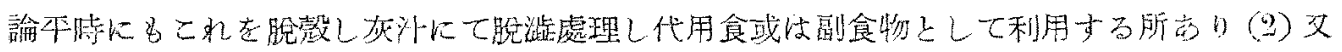

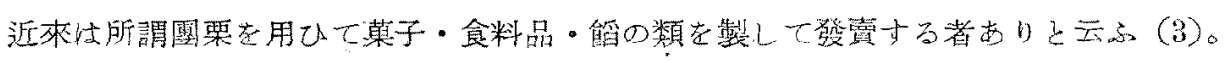

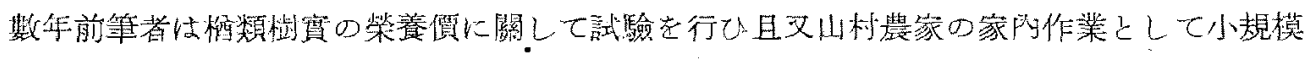

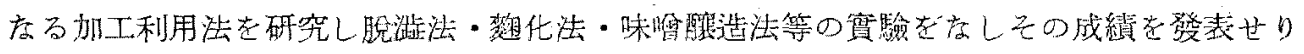

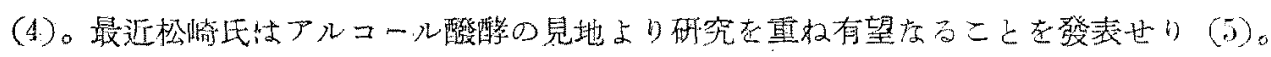

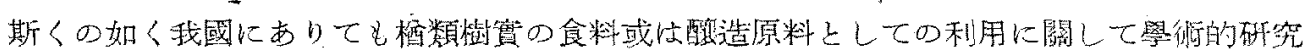
の見る心゙きの出づるに至れるが遺憾ながらとの種惯中に多量のタンニンを含有するが孚に

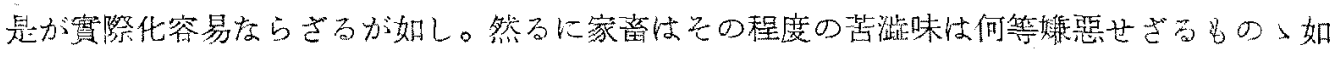

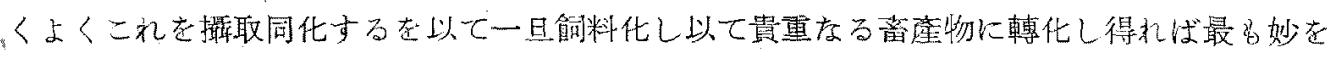
得たる活用法と稱し得へし。

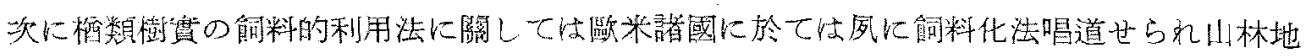

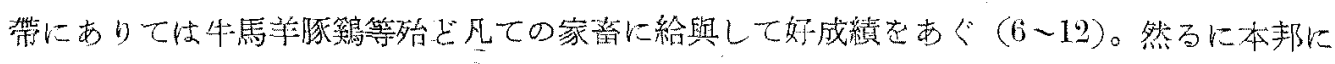

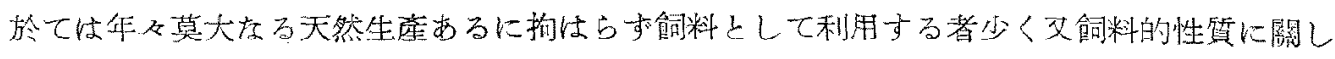

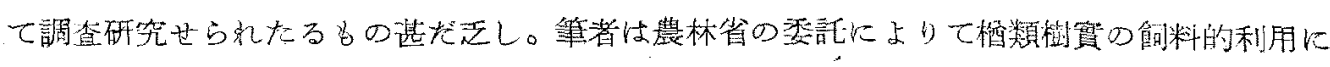
つをて寔驗研究せるにより先づその一般性質道に一般成分に閵する報告をなすべし。
\end{abstract}

\section{II. 楢類の植物學的性诈}

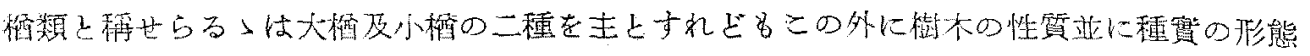

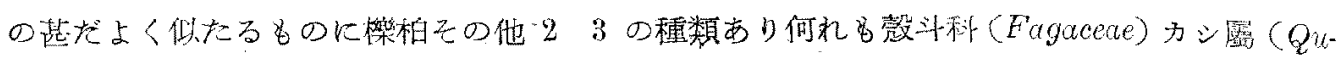

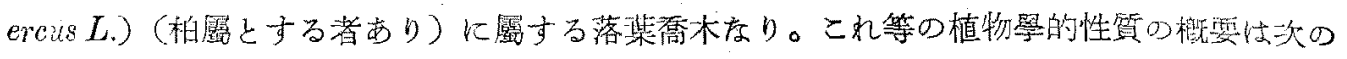
如代 $(13,14)$ 。

1. 大筑 


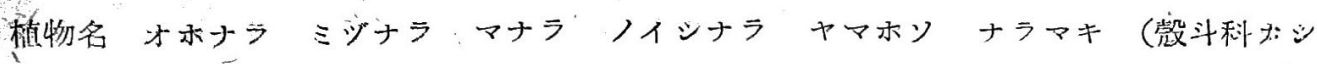
曧)

學名 Quercus crispula, Bu,rme 又付Q. grosseserata, BLUME)

分布 本州 四國九州 北海道

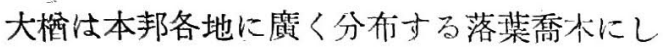
て通常次に述ぶる小枌に比し成長宜しく大朴上

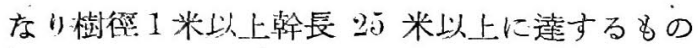
少からず。大梄疗る命名これに基くべし。樹幹 材質は稍々硬く質密なれども水分を含すこと多 量にして容易に然燒せず。水栖の別名あるはこ の故疗り。大楐の葉仿倒卵形にして緗邊に粗大 存る鋸齿あり葉柄岋甚た短し。これに反して次 に記す小梄の葉唡付絒くして長し。花は春 5 月 の頃開き種實は秋 10 月頃落葉前に熟して自然に

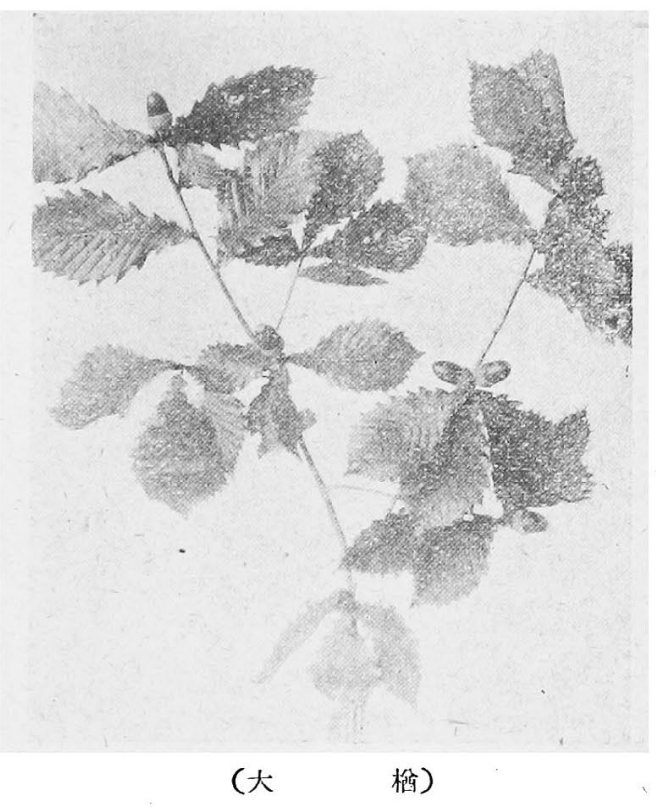

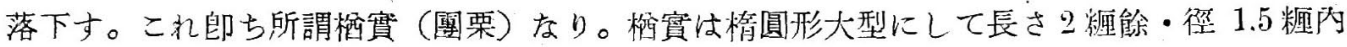

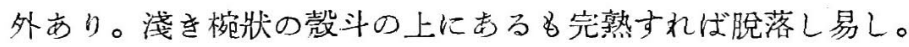

2. 小橪 (榴・枹)

植物名 コナラ’ナラ マキ ホソノホソクロナラ(殼斗科カシ屬)

學名 Quercus glandulifera, BLuxE

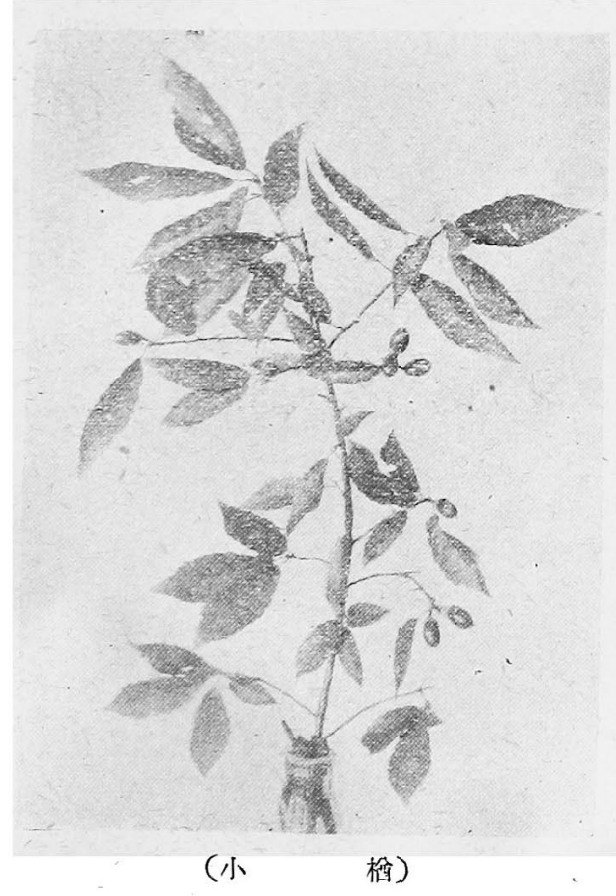

分布 本州四國九州 北海嗔

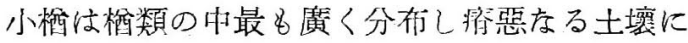
马よく生育する落葉喬木にして樹鿉 0.6 米幹長 15 米の大木より高さ1米队外の小灌朴に至るまで甚 たよく結算す。葉は倒卵形にして周緣に粗大なる 鋸齔あり荣柄は細くして長く前揭の大楢と容易に 區別し得。花怙 5 月頃柴と其に開を種竇は秋 10 月頃落葉に先たちて完熟し落下す。小怔の種實は 大楅の種筫に比し小槜圓形にして通常長さ 2 糎以

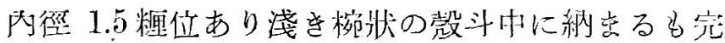
熟すれ代容易に脫落す。

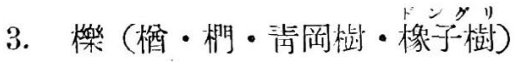

植物名クヌギ クニギ. トングリフシマキ カタギ（凯斗科うシ疑） 
名 Quercus acutissima, CARR 又は $Q$. serrata, ThunB

- 分死本州四國儿州

櫟怙暖地によく㢣茂する落葉喬木にして樹得 0.6 米幹長 15 米に及ぶ。浆は長惰測形にして桨 柄稍々長し。花は5月に開を種實は秋 10 月頃

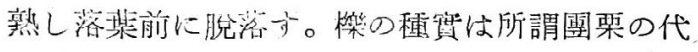
表的のものにして徑長さ共に約 2 糎にして刺毛 狀鱗片を有する㷫斗中に深く㰧る。

4. 柏 (期俳)

植物名カシハハハソ ホーソ モチガシ 八(耀斗科力シ盧)

學名 Quercus dentata, THUNB

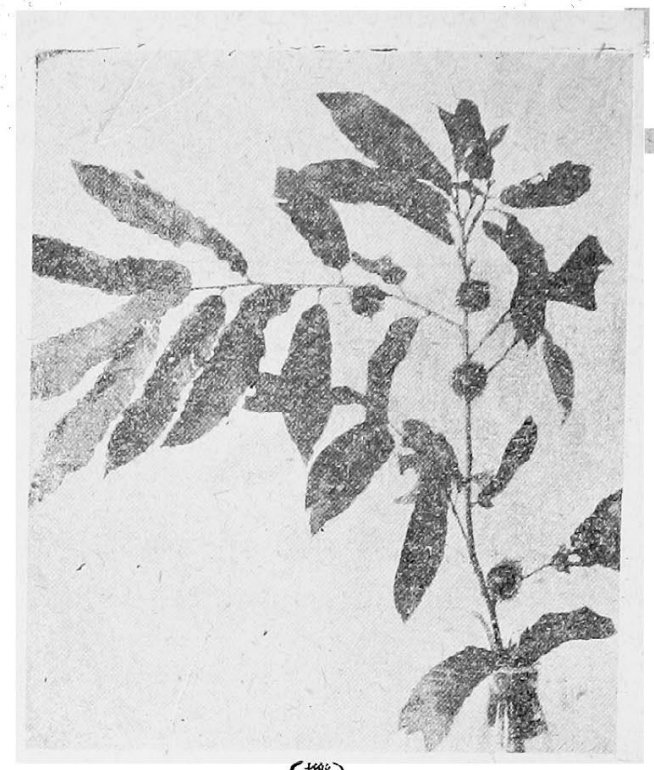

(橪)

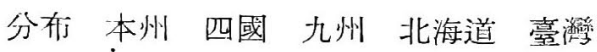

柏は暖地より寒地に至るまで廣く分布しよく繁茂する落某喬木にして樹徑 0.6 米高さ 15

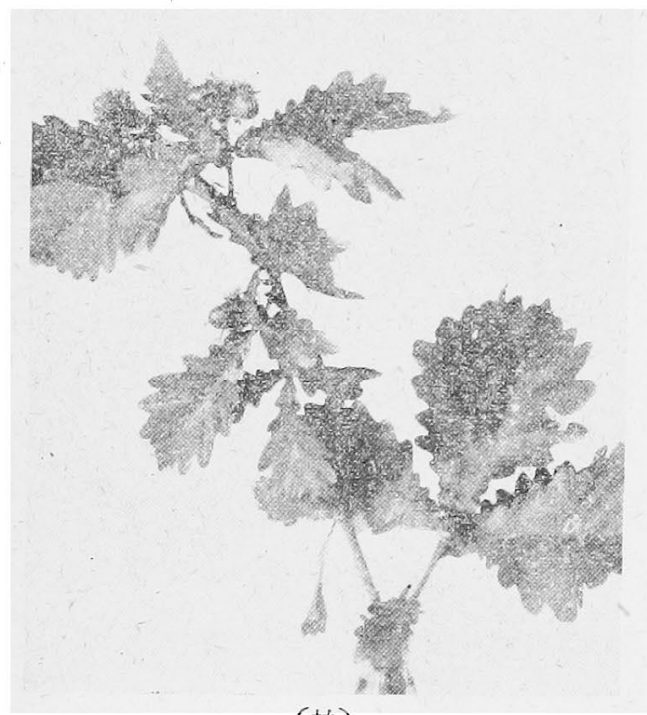

（柏） 米に菩す。茌は厚くして廣く倒卵形をなしその 周緣に波狀葱を有す。所謂柏飭の包として用ひ らるつは是なり。秋に至れば枯葉は容易に落ち ず翌春新葉發芽の前に至りて落つ。花は 5 月に 開き種實は秋 10 月に熟し自然に落下す。柏の 實は楢類樹實中にては比較的大形にして長さ】

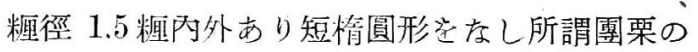
代表的のものなり。本樹實忌毛狀鱗片を有する 繁斗中に納まり完熟せば容易に脫落す。

5. 其他落葉喬木にして梲類に似をる樹種に 次の如を名の古り。

エゾミゾナラは大栖の變種にして北海道權太

に生育す。

モンゴリナラ（オホバナラ コバガシハ カラフトガシハ モウコガシハ）估北海道櫒太 に生育する落菜喬木なり。

ナラガシハ（カシハナラ カシハハハソ ワウゴンガシハ）は本州中南部及九州に生育す る落葉喬木なり。

ホソバガシハ（ナガバガシハ サハグリ カシハコナラ）は本州北中部に生有する落葉喬 木にして柏に似たる小葉を有す。 
アベマキ(ロルククメギ ワタクヌギ,ナベクメギ) は本州中南部, 四國, 九州火生育する

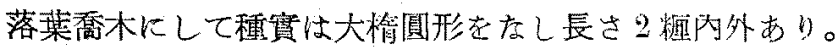

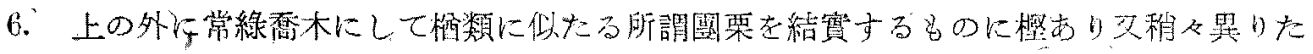

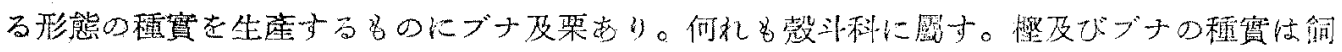
料として谌だ有望なるが故に後報に記述すべし。

\section{III. 橪類澍宽の一般性誓}

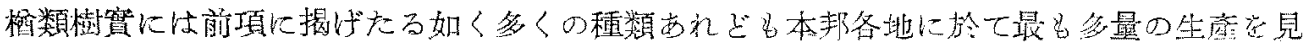

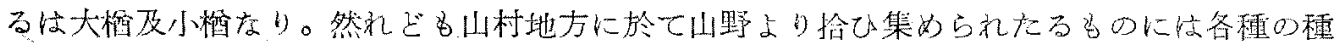

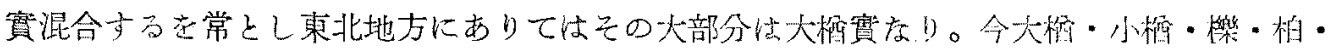

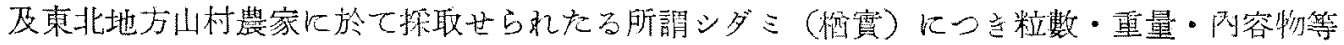

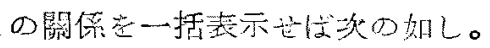

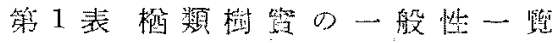

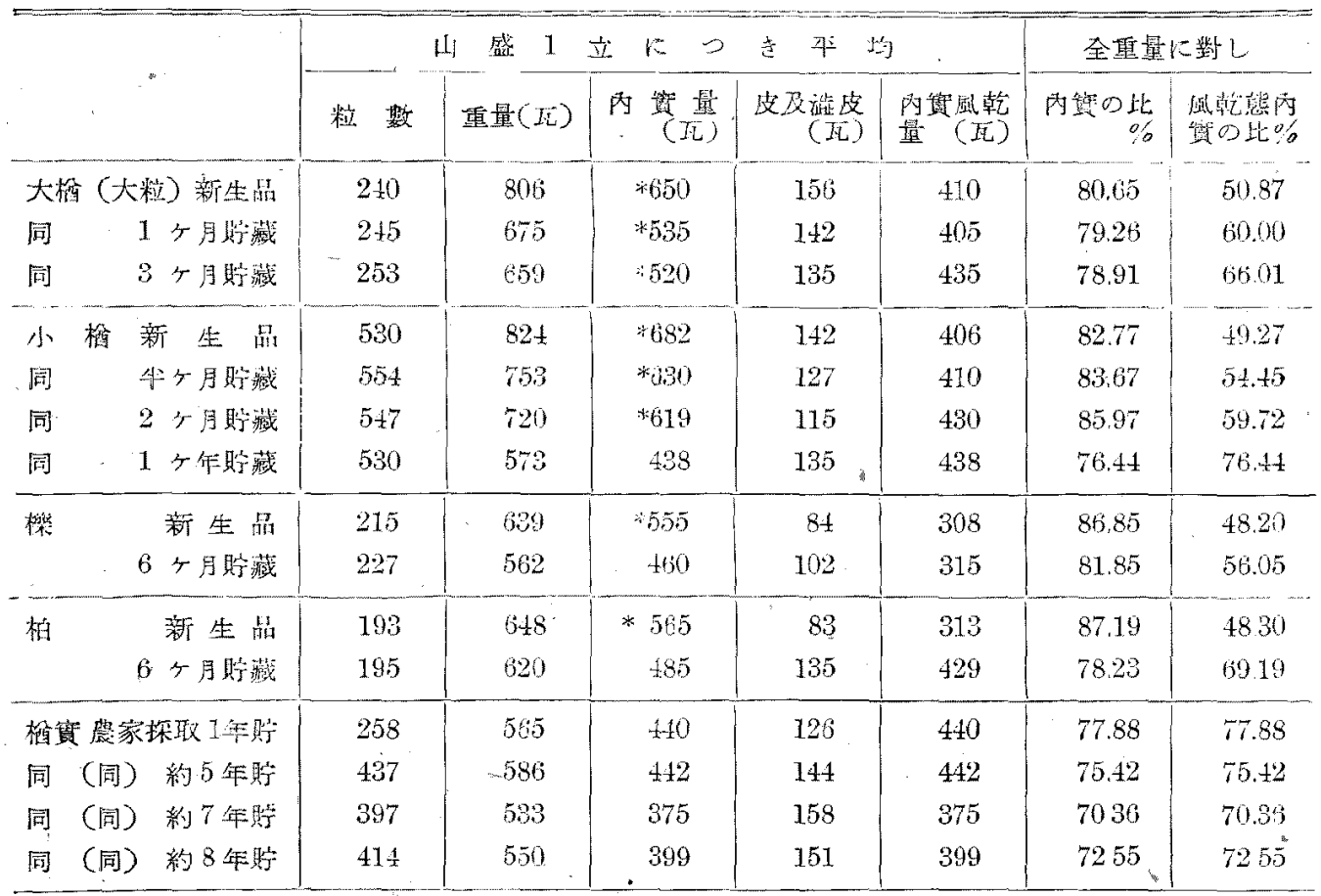

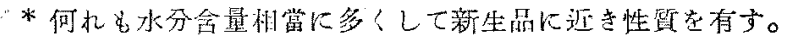

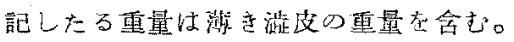

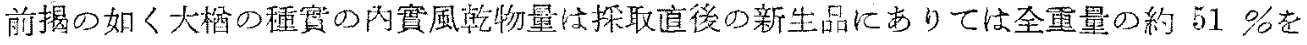

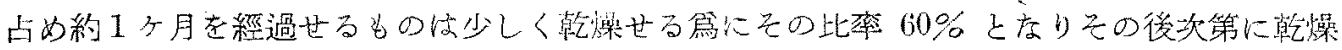

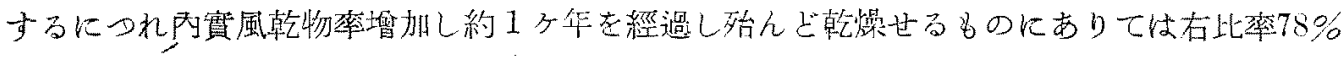
可外已后后を知社り。

同㥞に小梄にありては種賽の全重量に對する內賽風乾重量の比率は新生品にありては49\%

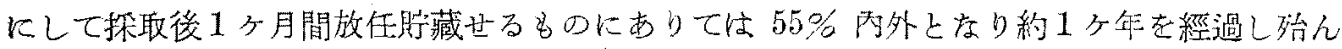


ぞ乾燥せるものにては 76\%不外症り。

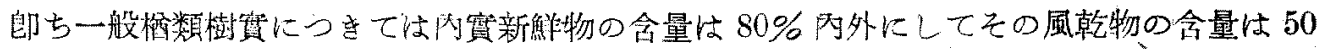

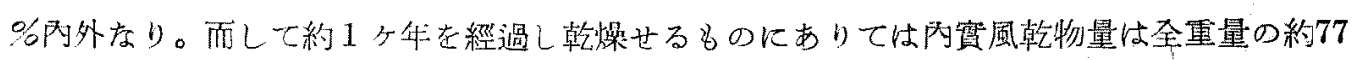

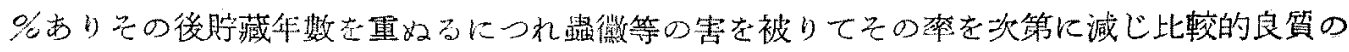
種實にありても $75 \%$ 以下に低下するを常とす。

今東北地方山村農家より得たる概實新鮮物（探取後約 1 ケ月桱過）につき調查せし結果本 均值を爱約せ代次の如し。

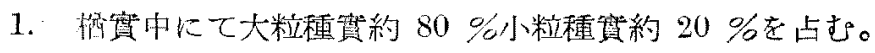

2. 粉寶奔央量の內譯次の如し。

丙害重量約 $80 \%$ 乙の水分会量約 $40 \%$

改㯏重量約 $20 \%$ その水分合量的 $25 \%$

\section{IV. 梄類 樹實の一般成分}

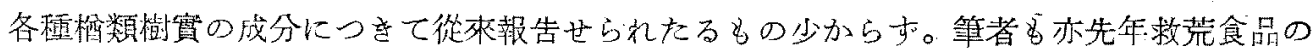
見地より研究を行ひ今亦鸽料的利用の見地より研究を重ねをり。䖯にそれ等の成續を一括表 示すべ。

第 2 表樽類澍實の一般成分 $(\%)$

\begin{tabular}{|c|c|c|c|c|c|c|c|c|c|c|}
\hline & & & 水 分 & 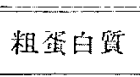 & 粗 脂 油 & 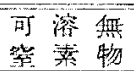 & 粗 維 維 & 灰 分 & 篟 & 䓂 \\
\hline \multicolumn{11}{|c|}{ 乾燥脫款せるもの } \\
\hline 大 & 粘 & 1 & 15.05 & 4.68 & 2.86 & 73.12 & 2.24 & 2.05 & 岩 & 田 \\
\hline 同 & & 2 & 1338 & 5.16 & 1.89 & 75.72 & 1.93 & 1.92 & 同 & \\
\hline 同 & & 3 & 13.95 & 5.32 & 2.43 & 74.14 & 2.01 & 2.15 & 同 & \\
\hline 同 & & 4 & 9.53 & 6.84 & 162 & 78.39 & 1.21 & 2.41 & 同 & (4) \\
\hline 岡 & & 5 & 8.20 & 5.34 & 2.55 & 79.00 & 2.91 & 2.00 & 同 & $(4)$ \\
\hline 小 & 蹈 & 1 & 12.50 & 4.40 & 3.25 & 74.64 & 2.68 & 2.53 & 同 & \\
\hline 同 & & 2 & 11.83 & 4.51 & 2.94 & 75.70 & 2.44 & 2.58 & 同 & \\
\hline 闹 & & 3 & 7.81 & 4.05 & 2.43 & 81.44 & 1.98 & 2.29 & 同 & (4) \\
\hline 闰 & & 4 & 7.43 & 557 & 2.70 & 79.87 & 2.75 & 2.18 & 同 & $(4)$ \\
\hline 懒 & & 1 & 12.79 & 5.27 & 3.95 & 73.96 & 2,06 & 1.97 & 同 & \\
\hline 同 & & 2 & 7.52 & 6.13 & 5.12 & $(68.23)$ & - & 2.23 & 闰 & $(4)$ \\
\hline 柏 & & 1 & 13.46 & 4.01 & 2.00 & 76.56 & 1.92 & 2.05 & 同 & \\
\hline 同 & & 2 & 5.47 & 4.89 & 1.74 & $(76.53)$ & - & 2.50 & 同 & $(4)$ \\
\hline \multicolumn{11}{|c|}{ 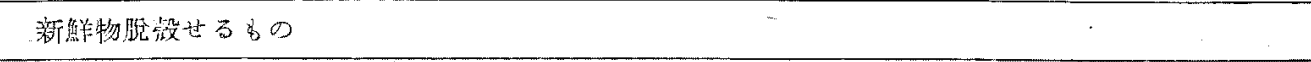 } \\
\hline 大 & 梅 & 6 & 4117 & 3.29 & 1.86 & 50.68 & 1.70 & 1.35 & 同 & \\
\hline 小 & 杼 & 5 & 39.72 & 3.15 & 2.27 & 51.06 & 1.92 & 1.88 & 同 & \\
\hline 萏 & (混 & 合) & 38.49 & 347 & 1.97 & 52.03 & 2.04 & 2.00 & 同 & \\
\hline 槚 & $C 大$ & 粒) & 46.05 & 2.81 & 0.59 & 47.66 & 2.35 & 0.54 & 古川 & 等 (15) \\
\hline 同 & (小 & 粒) & 37.83 & 2.90 & 2.01 & 53.83 & 2.61 & 0.82 & 同 & (15) \\
\hline 柏 & & & 45.35 & 2.80 & 5.36 & 40.41 & 4.67 & 1.40 & 同 & (15) \\
\hline
\end{tabular}




\begin{tabular}{|c|c|c|c|c|c|c|c|c|}
\hline . & 水 分 & 粗蛋白筑 & 粗脂油 & 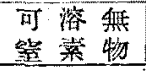 & 粗維維 & 灰 分 & 偕 & 洘 \\
\hline 同 & 34.90 & 4.67 & 4.03 & 50.36 & 4.17 & 1.87 & \multicolumn{2}{|c|}{ 解生試 (14) } \\
\hline \multicolumn{9}{|c|}{ 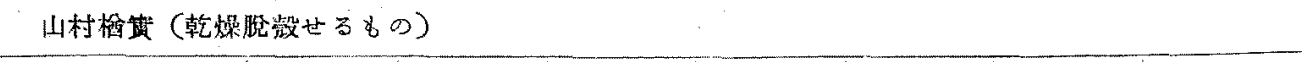 } \\
\hline 1. 岩 手 & 13.79 & 5.32 & 1.72 & 75.56 & 1.76 & 1.85 & 岩 & \multirow[t]{5}{*}{ 明 } \\
\hline 2. 同 & 14.17 & 5.60 & 1.66 & 74.11 & 1.89 & 2.57 & 同 & \\
\hline 3. 毒 森 座 & 13.98 & 5.16 & 1.81 & 75.17 & 1.92 & 1.96 & 同 & \\
\hline 4. 秋 时 模 & 10.57 & 5.03 & 1.95 & 77.76 & 2.50 & 2.19 & 同 & \\
\hline 5. 山形 㡾 & 9.58 & 5.86 & 2.16 & 77.64 & 2.74 & 2.02 . & 阔 & \\
\hline 桶 (12 年眝藏) & - & 5.27 & 1.60 & $(75.74)$ & - & 1.96 & 同 & (4) \\
\hline 同 (30 年詝藏) & $\longrightarrow$ & 4.84 & 2.33 & $(73.16)$ & - & 1.86 & 同 & (4) \\
\hline 小 楿 (發菏) & $\longrightarrow$ & 5.52 & 3.27 & $(71.46)$ & 2.87 & 2.40 & 同 & (4) \\
\hline (同) & - & 5.65 & 2.41 & $(71.81)$ & 2.90 & 2.58 & 同 & (4) \\
\hline 新鮮投附松筫: & 36.00 & 3.26 & 1.80 & 48.71 & 8.40 & 1.83 & 同 & \\
\hline 皮款風乾 & 6.38 & 3.05 & 1.39 & 44.87 & +2.85 & 1.46 & 同 & \\
\hline 同 新 鮮 & 26.06 & 2.41 & 1.10 & 35.44 & 33.84 & 1.15 & 同 & \\
\hline
\end{tabular}

括弧队数字は溉粉含皇を示す

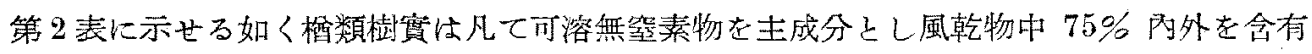

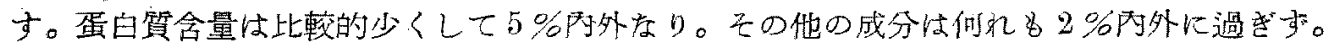
次には參考の篇に歐米諸國に於ける團栗（主に梄類樹實）の分析表を揭ぐべし。（6-12， $16,17)$

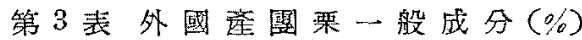

\begin{tabular}{|c|c|c|c|c|c|c|}
\hline 分析及報告㨋 & 水 分 & 粗蛋白質 & 粗 脂 油 & $\begin{array}{l}\text { 可溶舞 } \\
\text { 䇪溸物 }\end{array}$ & 粗 緋 維 & 灰 分 \\
\hline \multicolumn{7}{|c|}{ 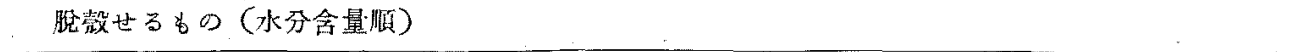 } \\
\hline DIETRICH & 50.15 & 3.13 & 2.52 & 40.36 & 2.55 & 1.29 \\
\hline VÖLCKER & 40.88 & 4.39 & 2.64 & 46.74 & 3.94 & 1.41 \\
\hline ENGELS ( 6 種平均) & 40.60 & 3.92 & 2.04 & 49.40 & 2.37 & 1.68 \\
\hline PETERMANN & 37.66 & 5.58 & 2.92 & 47.12 & 5.24 & 1.48 \\
\hline HONCAMP & 35.0 & 4.9 & 3.8 & 49.7 & 4.4 & 2.2 \\
\hline KELLNER & 35.0 & 49 & 3.5 & 50.1 & 4.5 & 2.0 \\
\hline Moser & 32.03 & 4.19 & 4.00 & 50.28 & 6.50 & 3.00 \\
\hline 同 & 24.06 & 7.17 & 5.45 & 53.72 & 6.50 & 3.10 \\
\hline PETERMANN & 22.83 & 6.91 & 3.61 & 58.43 & 6.49 & 1.73 \\
\hline BOUSSINGAULT & 20.00 & 5.00 & 4.30 & 64.50 & 4.60 & 1.60 \\
\hline WOLFF & 17.0 & 5.1 & 4.0 & $6 \pi .4$ & 4.5 & 2.0 \\
\hline KÜHN & 15.80 & 5.03 & 4.35 & 67.15 & 5.84 & 1.83 \\
\hline KELLNER & 15.0 & 6.5 & 4.6 & 65.5 & 5.9 & 2.5 \\
\hline HONCAMP & 14.4 & 6.8 & 4.6 & 65.9 & 5.7 & 2.6 \\
\hline ENGELS (6種平均) & 14.4 & 5.6 & 4.1 & 69.2 & 5.1 & 1.6 \\
\hline 同 & $114-20.0$ & $5.0-3.3$ & $3.6-5.4$ & $64.8-72.0$ & $4.6-5.9$ & 1.6 \\
\hline PETERS & 14.30 & 5.80 & 3.60 & 69.90 & 4.80 & 1.60 \\
\hline KRANFIELI & 13.86 & 788 & 4.57 & 67.82 & 3.68 & 2.24 \\
\hline STÖCKHARDT & 13.50 & 8.91 & 4.84 & 74.78 & 3.98 & 1.99 \\
\hline DIETRICH & 11.40 & 5.45 & 3.99 & 71.98 & 5.08 & 2.90 \\
\hline
\end{tabular}




\begin{tabular}{|c|c|c|c|c|c|c|}
\hline 分析及赫紫者 & 水 & 粗盆白㓋 & 粗 脂 溍 & 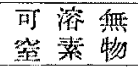 & 粗 㱍 維 & 战分 \\
\hline BAKER \& HULTON & 3.32 & 7.50 & 4.70 & 79.50 & 2.28 & 2.70 \\
\hline 同 & 1.45 & 6.65 & 5,00 & 82.45 & 2.20 & 2.25 \\
\hline
\end{tabular}

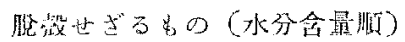

\begin{tabular}{|c|c|c|c|c|c|c|}
\hline WOLEF & 55.3 & 2.5 & 1.0 & $3 \pm .8$ & 4.4 & 1.1 \\
\hline HONCAMP & 50.2 & 8.2 & 2.3 & 36.3 & 6.8 & 1.2 \\
\hline KELLNER & 50.0 & 3.3 & 2.4 & 36.3 & 6.8 & $1.2^{\infty}$ \\
\hline MÓRRISON & 50.0 & 32 & - & 25.0 & 9.9 & 1.2 \\
\hline ENGELS（6栭平均） & 89.04 & 3.53 & 1.89 & 47.32 & 6.53 & 1.69 \\
\hline MORRISON & 37.6 & 3.3 & 3.7 & 48.0 & 11.3 & 1.4 \\
\hline KÖNG（10程平百） & 37.12 & 4.11 & 3.05 & 45.27 & 8.95 & 1.50 \\
\hline KELLNER & 35.0 & 4.3 & 3.2 & 47.1 & 8.9 & 1.5 \\
\hline HONCAMP & 18.5 & 7.5 & 4.0 & 50.0 & 9.0 & 20 \\
\hline KEI,INTE & 150 & 5.7 & 4.1 & 61.6 & 11.6 & 2.0 \\
\hline
\end{tabular}

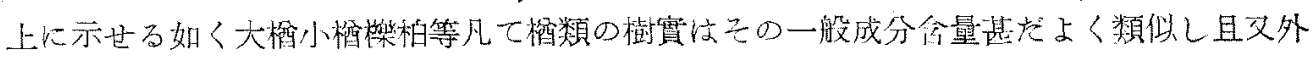

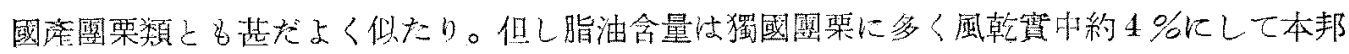

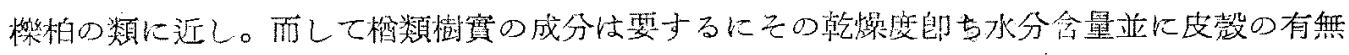

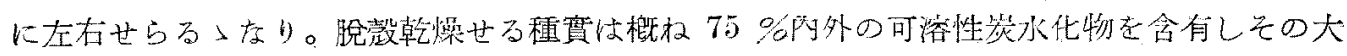

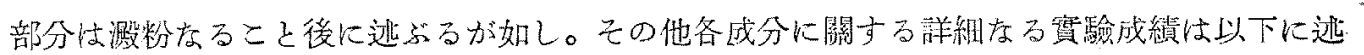
ぶベL。

\section{V. 瓷賽の蛋白㬏}

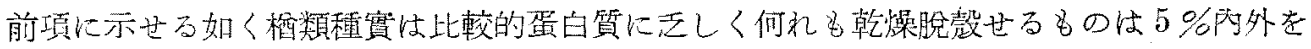

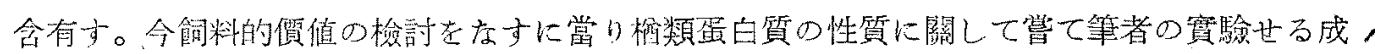
續を次に引用す心゙し( 1 。

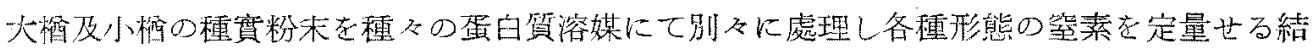
果を表示せば次の如し。

第 4 表 㧗類種惯蛋白質の溶解性

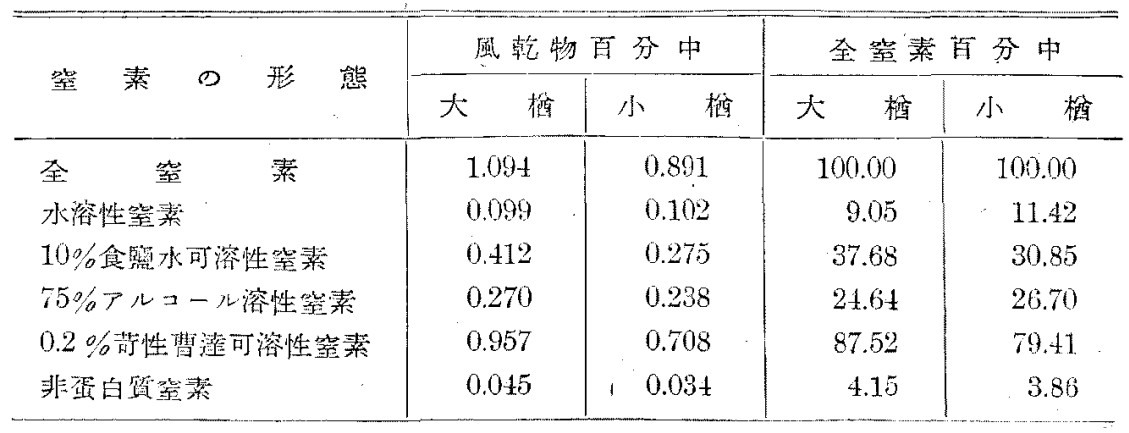

右の表に示せる如く粞類種蜜の蛋白質は大部分師ち $96 \%$ \%は具正蛋白質にして非蛋白質は

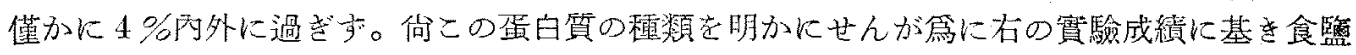
水可溶性䇪素より非蛋白質窒素を控除したる\&のをアルビュミン及グロビュリン形熊となし 


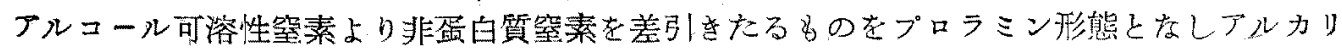
可溶性空菜よりアルビニミン・グロビニリン・プロラミン・非蛋白質各形態空素を控除しダ ルテリン態と見做し各ぬに 6.25 を乘じ各蛋白質の量を示せば㰡の如し。

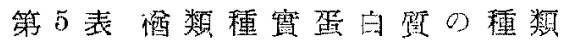

\begin{tabular}{|c|c|c|c|c|}
\hline \multirow{2}{*}{ 日 啠 $の$ 種 類 } & \multicolumn{2}{|c|}{ 風乾物 100 分中。 } & \multicolumn{2}{|c|}{ 全零白啠 100 分中 } \\
\hline & 大梄 & 小 & 大 & 小 \\
\hline アルビュミン及ダロビュりン. & 2,29 & 1.50 & 33.53 & 26.99 \\
\hline ブロラミン & 1.41 & 1.27 & 20.49 & 22,81 \\
\hline ダルテリン & 2.01 & 1.43 & 29.85 & 25.22 \\
\hline 不溶性蛋白貿 & 0.85 & 1.15 & 12.48 & $20.5 y$ \\
\hline 非蛋白筫合箱素物 & 0.28 & 0.22 & 4.15 & 3.86 \\
\hline 計 & 6.84 & 5.57 & 100.00 & 10000 \\
\hline
\end{tabular}

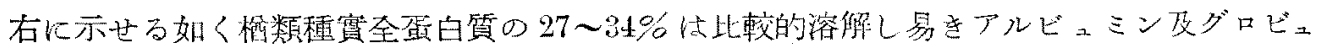

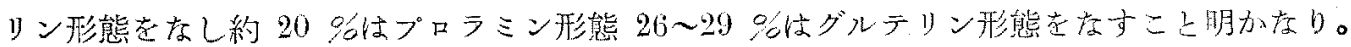

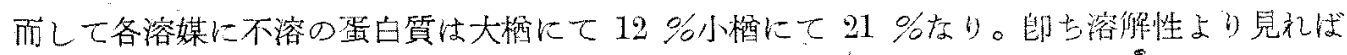

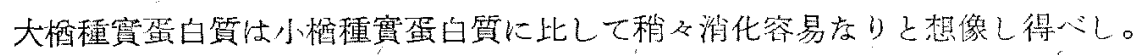

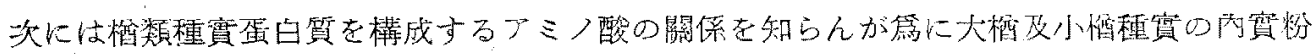
末をとのま〉 $20 \%$ 監酸中にて加熱加水分解すること 20 時間の後バンスライク法によりて

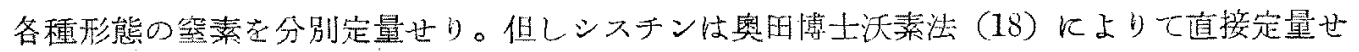
り。その結果を要約表示せ代㰠の如し。

第 6 裴 楢類種實のアミ, 酸組成

\begin{tabular}{|c|c|c|c|c|}
\hline \multirow{2}{*}{ 堂 真 形 態 } & \multicolumn{2}{|c|}{ 風乾物 100 分中 } & \multicolumn{2}{|c|}{ 金等素 100 分中 } \\
\hline & 大榷 & 小椎 & 大唡 & 小 \\
\hline 全 & 1.094 & 0.891 & 100.0 & 100.0 \\
\hline 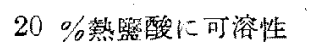 & 1.008 & 0.789 & 92.1 & 88.5 \\
\hline ヒューミン態 & 0.033 & 0.029 & 3.0 & 3.2 \\
\hline アマイド態 & 0.190 & 0.102 & 17.4 & 11.5 \\
\hline モノアミノ䁏湂全 & 0.532 & 0.473 & 48.6 & 53.1 \\
\hline デアミノ酸摆全 & 0.266 & 0.188 & 24.3 & 21.1 \\
\hline 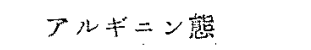 & 0.137 & $0.076^{\circ}$ & 12.5 & 85 \\
\hline ヒスチギン態 & 0.097 & 0.082 & 8.9 & 9.2 \\
\hline システン態 & 0.008 & 0.006 & 0.7 & 0.7 \\
\hline y ジン热 & 0.024 & 0.024 & 22 & 2.7 \\
\hline
\end{tabular}

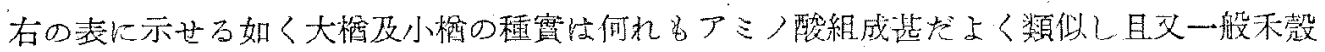

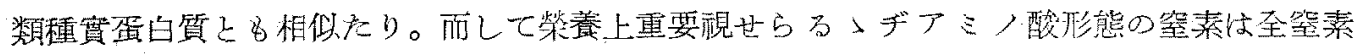
100 分中大標にて $24 \%$ 小梄にて $21 \%$ \%してとの中アルギニン及とスチデン多くリジン熊

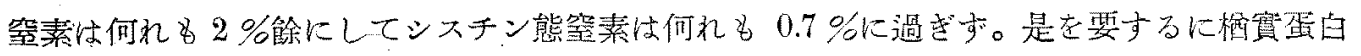

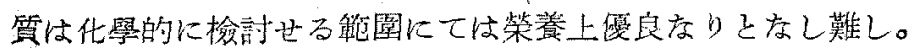




\section{VI．梄赛 $の$ 脂 油}

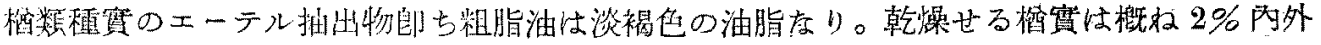

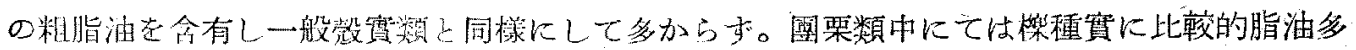

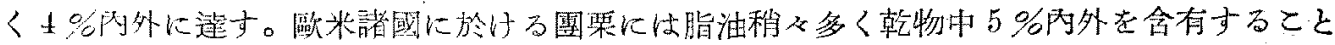

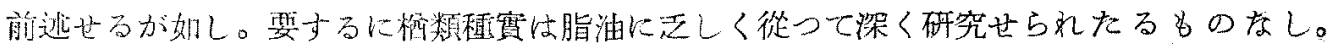
BLASDALE（19）は娄栗の一種 Quercus argifolia の油脂につき試驗を行ひ坎の如き結果を 行たり。

\begin{tabular}{|c|c|c|}
\hline 此重 (15 度拏にて & 0.9162 & 沃装想 \\
\hline 固化點 (搔) & 10 度 & 属折坐 \\
\hline 襝化䫄 & 199.3 & \\
\hline
\end{tabular}

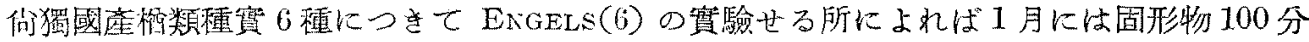
中に粗脂油含量 2.66 3.96 平均 3.39 にしてその队遊離脂肪酸含量はオレイン酸として固形 物 100 分中 0.18 あり。同一種實を 7 月迄貯へたるものは粗脂油 $3.41 \%$ 遊離脂肪酸 $0.23 \%$ 存

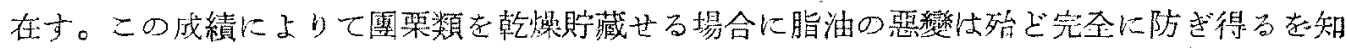

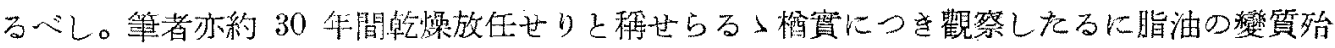
そ無意知りたり。

\section{VII. 樽實の炭 水化物}

樎類種賽の主成分は䈐水化物なること先に揭げをる一般成分表によりて明かなり。師方乾

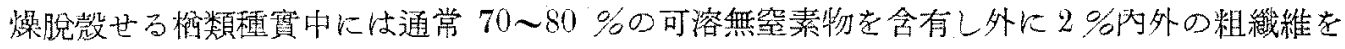
含有す。筆者は簡單に是等可溶無䇪素物及炭水化物の内容を知らんが爲に少しく賽驗を重权 地り。之の概要次の如し。

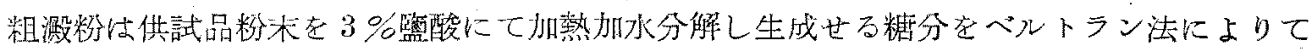
定量しこれより算出せり。この队とは還元糖・非還元糖その他類似作用物質を包含すへきに 上り齿澱粉と命名せり。

罡元結は供試品粉末を冷水にて浸出し浸出液に少量の硫酸銅を加へて蛋白質及タンニンの

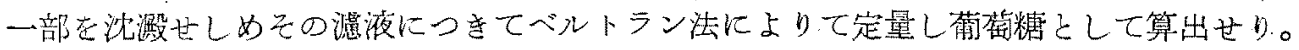

ペントザンはトルレンス・クレーベル法によりて定量し一般ペントザンとして表せり。

タンニン位供試品粉末泠水にて充分浸出せ方後ぜラチン法に上つて定量しタェルシタン ニンとして算出せり。

有機酸は供試品粉末を 50 \%中性アルコールにて漫出しフェノールフタレンを試藥として 0.1 規定苛性藏達液にて立分着色する迄適定したる後クエン酸として表せり。

可溶無空素物攻粗繊維は前据の表より膞載せり。 


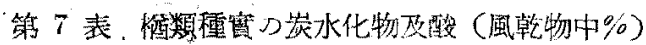

\begin{tabular}{|c|c|c|c|c|c|c|c|c|c|}
\hline$\left(\begin{array}{ccc}\text { 璄政 } \\
\vdots & 8\end{array}\right)$ & & 末 分 & 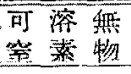 & 粗 筑粉 & 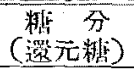 & $\begin{array}{rll}3 & y & 1 \\
47 & y\end{array}$ & タンニン & 有機酸 & 粗、維赫 \\
\hline “大 輗” & 1 & 15.05 & 73.12 & 64.02 & 13.94 & 241 & $6.86^{\circ}$ & 2.57 & $2.2 t$ \\
\hline 同 & 2 & 13.38 & 75.72 & 65.92 & 10.58 & 3.10 & 5.56 & 2.61 & 1.93 \\
\hline 同 & 3 & 13.95 & 74.14 & 63.18 & 8.31 & 2,65 & 6.49 & 2.05 & 2.01 \\
\hline 同 & 4 & 9.53 & 78.39 & 70.55 & 9.75 & - & 5.40 & - & 1.21 \\
\hline 同 & 5 & 8.20 & 7900 & 70.08 & 11.06 & - & 7.90 & $\longrightarrow$ & 2.91 \\
\hline 平 & 均 & 12.02 & 76.07 & 66.75 & 10.73 & 2.72 & 6.44 & 2.41 & 2.06 \\
\hline 小 梄 & 1 & 12.50 & 74.64 & 63.71 & 14.02 & 2.77 & 6.36 & 2.35 & 2.68 \\
\hline 同 & 2 & 11.83 & 75.70 & 66.25 & 8.94 & 3.18 & 6.92 & 2.60 & 2.44 \\
\hline 同 & 3 & 7.81 & 81.44 & 71.14 & 12.17 & - & 7.13 & $\longrightarrow$ & 1.98 \\
\hline 同 & 4 & 7.43 & 79.37 & 70.84 & 9.53 & - & 6.18 & 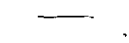 & 2.75 \\
\hline 平 & 均 & 9.89 & 77.79 & 67.99 & 11.17 & 2.98 & 6.65 & 2.48 & 2.46 \\
\hline 榴 & 1 & 12.79 & 73.96 & 65.80 & 8.10 & 3.58 & 3.18 & 1.26 & 2.06 \\
\hline 同 & 2 & 7.52 & - & 68.23 & 6.58 & - & 3.66 & - & - \\
\hline 平 & 均 & 10.16 & 73.96 & 67.02 & $7.3 \pm$ & 3.58 & 3.42 & 1.26 & 2.06 \\
\hline 柏 & 1 & 13.46 & 76.56 & 70.21 & 7.99 & 3.04 & 4.11 & 1.57 & 1.92 \\
\hline 同 & 2 & 5.47 & - & 76.53 & .7 .30 & - & 3.96 & $\cdots$ & - \\
\hline 、平 & 均 & 9.47 & 76.56 & 73.37 & 7.65 & 3.04 & 4.04 & 1.57 & 1.92 \\
\hline 山村樎害 & 1 & 13.79 & 75.56 & 66.23 & 6.92 & 2.61 & 5.81 & 2.20 & 1.76 \\
\hline 闹 & 2 & 14.17 & 74.11 & 65.15 & 12.09 & 2.47 & 5.16 & 2.14 & 1.80 \\
\hline 间 & 3 & 13.98 & 75.17 & 67.18 & 13.50 & 2.95 & 5.99 & 1.38 & 1.92 \\
\hline 同 & 4 & 19.57 & 77.76 & 70.25 & 9.84 & 3.27 & 7.04 & 2.60 & 2.50 \\
\hline 同 & 5 & 9.58 & 77.64 & 68.59 & 10.72 & 3.60 & 6.81 & 2.47 & 2.74 \\
\hline 平 & 均 & 12.42 & 76.05 & 67.48 & 10.61 & 2.98 & 6.16 & 2.18 & 2.16 \\
\hline
\end{tabular}

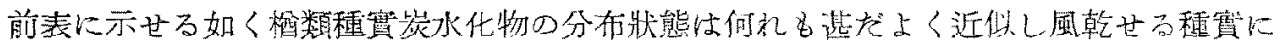

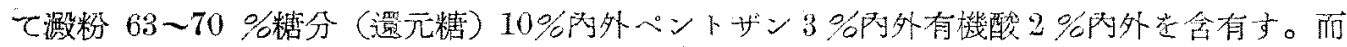

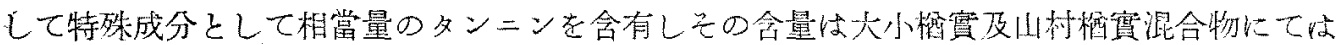

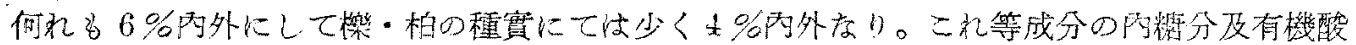

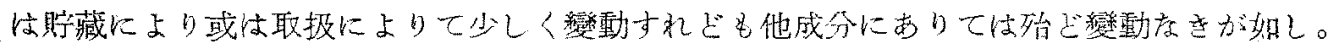

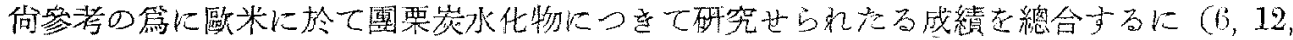

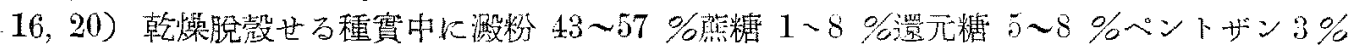

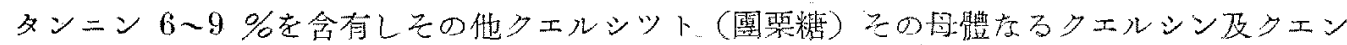

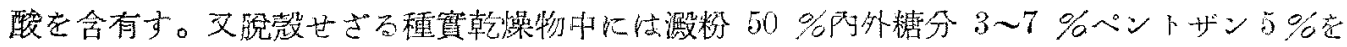

第 8 表 獨魀團票の炭水化物

\begin{tabular}{|c|c|c|c|}
\hline (說殸せるもの) & 新䱊物中? & 固形肳中\% & 同平坞 \\
\hline 湜 & & & 6.83 \\
\hline ベントザン & $1.62-$ & $2.70-3.22$ & 94 \\
\hline$\not 2 y=$ & 3.44 & $5.93-$ & 7.05 \\
\hline
\end{tabular}

含孙芝殼乾物中にはペントザン約 $16 \%$ \%

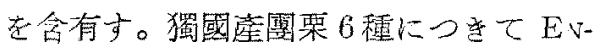
GELS（6）の研究せる結果を見るに次表 の如し。

是在要するに猫國に於付る團梁の成分 
は我國楖類澍蕒に选だよく類似する走知る。

\section{VIII. 栖 宜 の無機物}

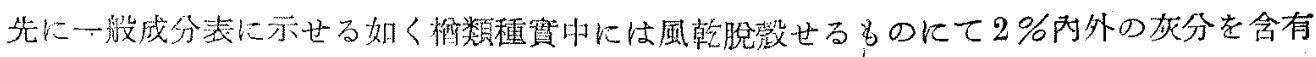

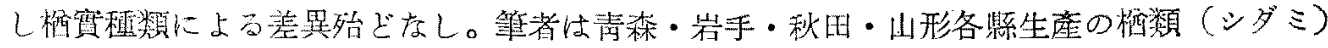

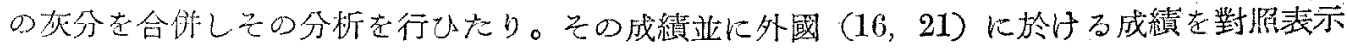
せば次の如し。

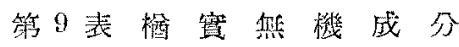

\begin{tabular}{|c|c|c|c|c|c|c|}
\hline & \multicolumn{2}{|c|}{ 筑 时（本邦虐梄） } & \multicolumn{2}{|c|}{ KÖNIG (16) HORNBER- } & WOLFF (21) \\
\hline & & 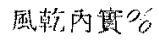 & 炏分 100 中 & 上 & 同 & 同 \\
\hline 炏分綑 & 量 & 2.120 & 100.00 & 100.00 & 100.00 & 100.00 \\
\hline 加 & 里 & 1.218 & 57.44 & 64.14 & 64.22 & 64.29 \\
\hline 曹 & 洼 & 0.054 & 2.57 & 0.63 & 0.64 & 1.02 \\
\hline 石 & 灰 & 0.129 & 6.08 & 6.91 & 6.94 & 7,14 \\
\hline 苦 & 土 & 0.158 & 7.45 & 5.29 & 5.28 & 5.10 \\
\hline 酸 化 & 鐵 & 0.027 & 1.26 & 1.01 & 1.01 & - \\
\hline 燐 & 酸 & 0.357 & 16.85 & 14.89 & 14.93 & 15.31 \\
\hline 硫 & 酸 & 0.082 & 3.89 & 4.17 & 4.18 & 4.08 \\
\hline 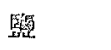 & 萦 & 0.064 & 3.00 & 1.76 & 1.75 & 2.04 \\
\hline 恄 & 酸 & 0.046 & 2.17 & 1.07 & 1.06 & 1.02 \\
\hline
\end{tabular}

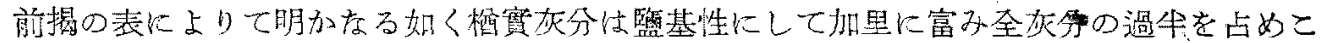

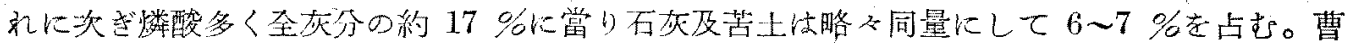

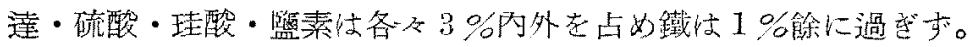

又 BRACONNOT (22) の研究によれば生國栗（水分 $32 \%$ ）中に加里 0.38 硫酸加里 0.19 監

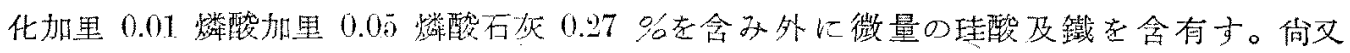

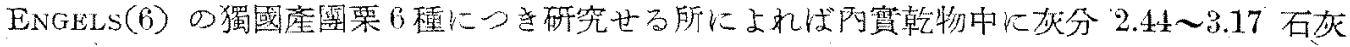

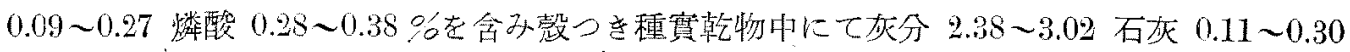

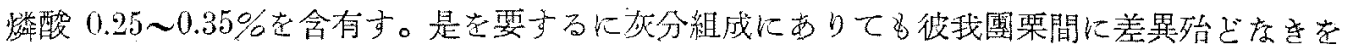
認むべし。

\section{IX. 要 、約}

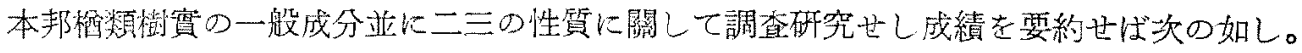

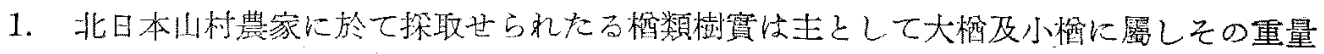

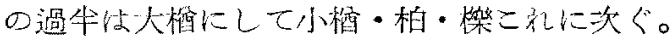

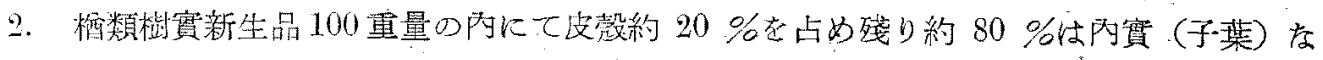

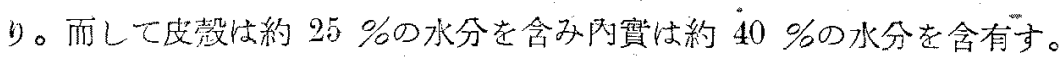

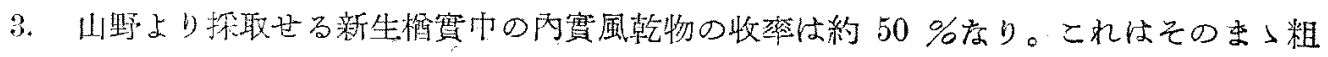
碎し飼料配合に供して可なり。 


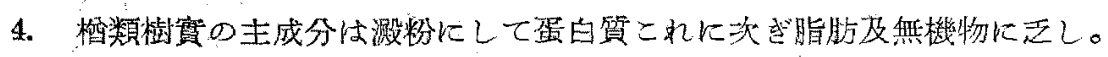

5. 梄類樹䆩蛋白質のアミノ酸中にはリジンシスナン汇しく從つてこれを飼料化するに當 りてて戊蛋白質の補給を必要とす。

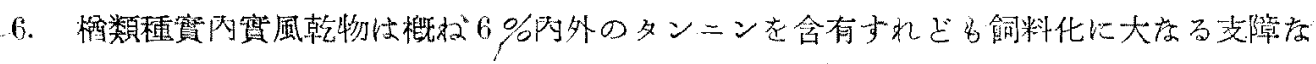
き程度症り。梄類の中にては㹸・柏の種類にタンニン少し。

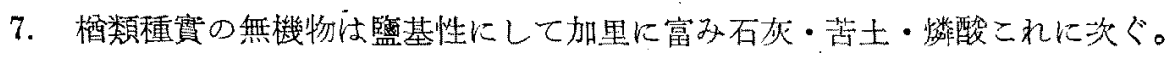

8. 栖類樹實の平均成分を一括表示世壮次の奶し。

\begin{tabular}{|c|c|c|c|c|c|c|c|}
\hline , & 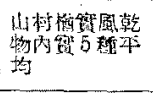 & 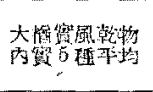 & 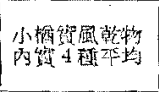 & 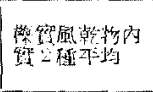 & 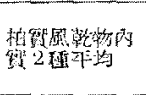 & 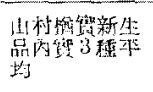 & 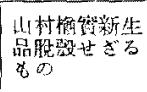 \\
\hline 水 & 12.42 & 12.02 & 9.89 & 10.16 & 947 & 39.79 & 36.00 \\
\hline 粗蛋白資 & 5.39 & 5.47 & 4.63 & 5.70 & 4.45 & 3.30 & 3.26 \\
\hline 粗 & 1.86 & 2.27 & 2.83 & $4.5 t$ & 1.87 & 2.05 & 1.80 \\
\hline 可溶拖等素物 & 76.05 & 76.07 & 77.79 & 73.65 & 76.56 & 51.24 & 48.71 \\
\hline 粗纖 & 2.16 & 2.06 & 2.46 & 2.06 & 1.92 & 1.89 & 8.40 \\
\hline 麻 & 2.12 & 2.11 & 2.40 & 2.10 & 2.28 & 1.74 & 1.83 \\
\hline 粗 潅 粉 & 67.48 & 66.75 & 67.99 & 67.02 & 73.37 & 46.39 & - \\
\hline 精分（悪元糖） & 10.61 & 10.73 & 11.17 & 7.34 & 7.65 & 7.30 & - \\
\hline ペントザン & 2.98 & 2.72 & 2.98 & 3.58 & 3.04 & 2.05 & $\ldots$ \\
\hline 夕夕 $\nu=2$ & 6.16 & 6.44 & 6.65 & 3.42 & 4.04 & 4.24 & - \\
\hline 有 & 2.18 & 2.41 & 2.48 & 1.20 & 1.57 & 1.50 & - \\
\hline
\end{tabular}

\section{參考文獻}

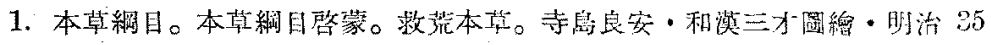

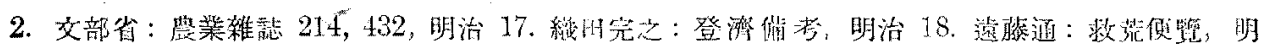

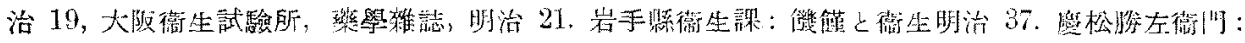

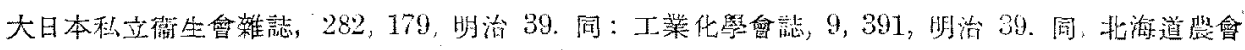

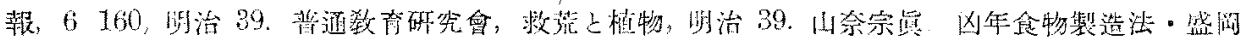

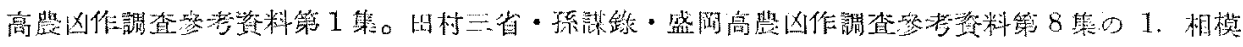

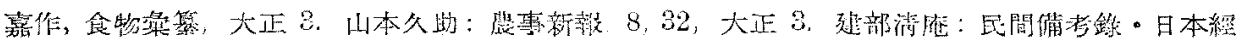

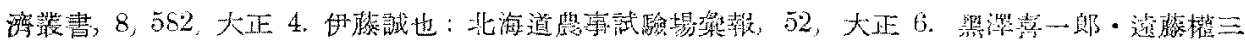

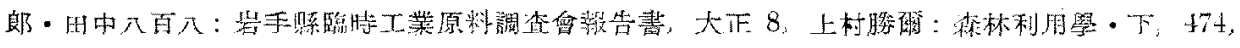

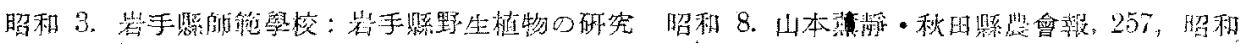

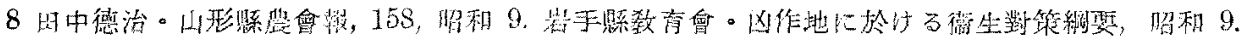

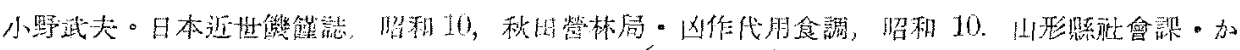

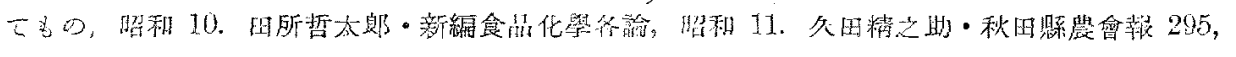
昭 11

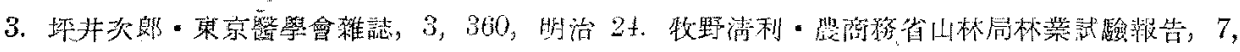

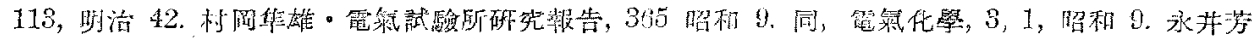

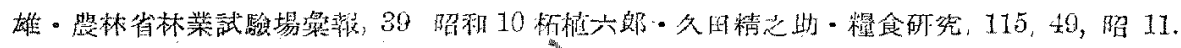

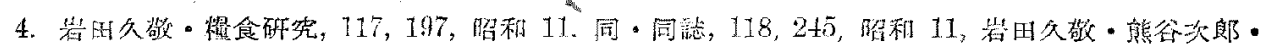

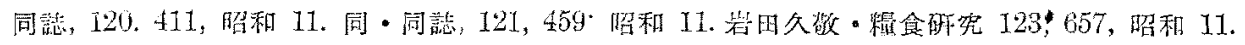

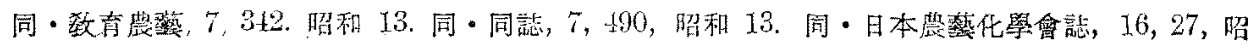
和 15 . 同・饲料學, 昭 12 .

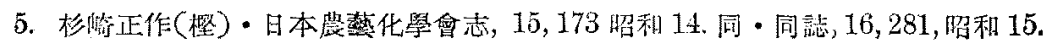


6. ENGELS: Landwirtschaf. Versuchest. 82. 93. 1913.

7. Kellner: Die Ernähr. d. Iandw. Nutatiere. 1924.

8. MOrRison : Feeds and Feeding. 1936. Henry \& MOrRison: Feeds and Feeding, 1922.

9. HANSSON : Fütterung der Haustiere. 1926.

10. POTT: Handb. d. tierischen Ernähr v. d. landw. Futtermittel. 1909.

11. Mangotd: Handb. d. Ernähr u. d. Stoffwechs. d. landw. Nutztiere. I. 1929. Honcamp: 同。

12. Winton: Structure and Composition of Foods. I. 1992.

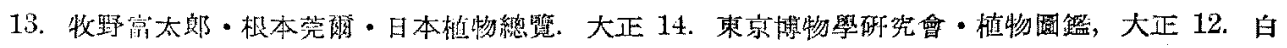

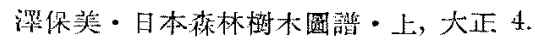

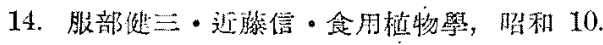

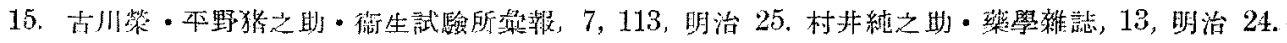

16. KüNIG: Chemie d. menschrich. Nahrungs-Genussm. I. 1903. II 1904.

17. WOLFE: Landw. Fütterungslehre. 1899.

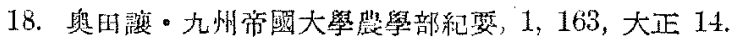

19. Blasdale: Jour. Soc. Chem. Ind. 206. 1896.

20. Wehmer: Die Phlazenstoffe. I. 1929. II. 1931. Wresner: Die Rohstoffe des Pfla nzenreiches. I. 1921. II. 1927. III. 1923. BAKER \& HULTON: Analyst. 42. 351.1917.

21. WOLFF's Table. 東宗㷞林學校, 1890. HORNDERGER: Landw. Vers-stat. 29. 284. 1883.

22. BRACONNOT: ENGELS 及 KÖNIG 參照。 